UDC 338.43

JEL Classification: Q13; Q16

DOI: https://doi.org/10.32317/2221-1055.202011090

R. M. BEZUS, doctor of economic sciences, professor

S. H. BURTAK, candidate of political sciences

L. S. KRIUCHKO, candidate of economic sciences

N. P. DUBROVA, candidate of economic sciences

\title{
Premises and prospects for organising and developing secondary and tertiary producers' cooperatives in Ukraine: the case of dairy service cooperatives
}

The purpose of the article is to identify the premises and prospects for organising and developing secondary and tertiary producers' cooperatives in Ukraine, specifically for dairy service cooperatives.

Research methods. The research uses dialectical methods of cognition and monographic method - for the analysis of works of Ukrainian and foreign scientists on the problem of agricultural dairy cooperation; empirical and graphical methods - to demonstrate the state of the cooperative movement in European countries and interactions between three levels of cooperatives; remote survey method - to find out the opinions of co-operators about secondary and tertiary cooperatives; abstract logical methods - for theoretical generalizations and formulation of conclusions.

Research results. Most cooperators seek a collective solution to the problems of a competitive business environment in Ukraine. The functioning of cooperative unions, which include dairy cooperatives (secondary cooperatives), improved interaction between participants in the dairy business and contributed to better organization of agricultural production in rural communities. According to the respondents' opinions, the tertiary cooperative is designed to support farmers and cooperatives in solving such significant problems as restrictive legislation, or to support in the process of such critical reforms for agricultural producers as land reform. Those organisations may be able to influence the market conditions, to raise the funding or subsidies for small-scale dairy farmers.

Scientific novelty. This article identified the reasons for small-scale dairy farmers to cooperate and their opinions about premises and prospects for organising and developing secondary and tertiary farming cooperatives in Ukraine. It highlighted perspective points of development and improvement for such organizations to support the further functioning of the rural dairy business in Ukraine. In particular, the respondents of surveyed secondary cooperatives are aware of prospective benefits from cooperative unions and expect something similar from starting the tertiary cooperative. They prefer those to be organised based on sectoral mandate and mainly concentrated on legislation and funding matters, but $80 \%$ of respondents have doubts about practical realisation of this idea because of such risks as corruption and shadow economy matters. It is important to stress that secondary cooperatives are the business organizations and in the worldwide experience aiming at marketing, processing or trading the production, gaining the bargaining power and market share.

Practical significance. Scientists and experts of the agricultural economy can use the results of the study to support the development of secondary and tertiary dairy service cooperatives for improving the working conditions in rural communities with cooperatives and business environment for small-scale dairy producers in Ukraine. Tabl.: 2. Figs.: 1. Refs.: 19.

Keywords: agricultural cooperatives; dairy cooperatives; cooperative union; cooperative; secondary and tertiary cooperatives.

Bezus Roman Mykolaiovych - doctor of economic sciences, professor, professor of the department of marketing, Dnipro State Economic and Agrarian University (25, S. Efremova St., Dnipro, 49600)

E-mail: bezusrm@gmail.com

ORCID iD https://orcid.org/0000-0001-5284-9178

Burtak Sofiia Hryhorivna - candidate of political sciences, training and gender program manager, Cooperative Academy (31, P. Kalnyshevskogo Ave, Dnipro, 49000)

E-mail: sofia.burtak@gmail.com

ORCID iD http://orcid.org/0000-0002-8578-0741

(c) R. M. Bezus, S. H. Burtak, L. S. Kriuchko, N. P. Dubrova, 2020 
Kriuchko Lesia Stanislavivna - candidate of economic sciences, associate professor (docent) of the department of marketing, Dnipro State Agrarian and Economic University (25, S. Efremova St., Dnipro, 49600)

E-mail: kriuchko.l.s@dsau.dp.ua

ORCID iD http://orcid.org/0000-0002-7490-3523

Dubrova Nataliia Petrivna - candidate of economic sciences, associate professor (docent) of the department of finance, banking and insurance, Dnipro State Agrarian and Economic University (25, S. Efremova St., Dnipro, 49600) E-mail: pts_fkg@meta.ua

ORCID iD http://orcid.org/0000-0001-8584-3338

Scientific problem. In 2019, the registries of the Ukrainian rural authorities suggested there were registered 1286 service cooperatives, and its number is 161 more than in 2018. Although according to the Ministry of Agrarian Policy and Food of Ukraine, the number of Ukrainian service cooperatives that has actually operated in 2019 is 735 . The dairy specialisation has been chosen by 186 of such cooperatives [1]. About $43 \%$ of officially registered cooperatives have lost their members but the registration is left uncancelled yet. The reason for such a situation is that the heads of inactive cooperatives have been started within several years after the disassociation from the Soviet Union and were similar to collective farms. Due to this, newly created structures were able to satisfy very little of producers' needs that make them look for other forms of cooperation.

Historically, Ukrainian (at the West) cooperative have been thriving at the beginning of the 20th century and the farmers understood the need for organised cooperative' relations [16]. The scarcity of natural and credit resources, knowledge, and working experience sharing, joined work for maximising the income, the competitive environment to work are the core reasons for adopting the innovative structure for Ukrainian farmers. The competition issues are exceptionally important nowadays when rural farmers have to fight COVID-19 related economic consequences, an ongoing decrease of productive cattle, and challenging competition with private agricultural enterprises. However, the big idea of effective cooperation has not been realised yet in Ukraine.

According to the Law of Ukraine "On Agricultural Cooperation", any cooperative has the right for voluntary founding or entering the cooperatives' union. Such unions, in their turn, have the right to the founding of the cooperatives' next level union according to the operating area or specialisation of member cooperatives [7]. Thus, a secondary cooperative is a cooperative in which all members are cooperatives, and tertiary cooperative is a cooperative, the members of which are secondary cooperatives [9].

Foreign cases of founding and running secondary and tertiary farming cooperatives describing both pros and cons of these unions may help to understand the premises and prospects for organising and developing secondary and tertiary farming cooperatives in Ukraine in the nearest future. For example, in the UK the cooperative unions are very helpful for farmers in their fight against prohibitive legislation in such cases as increasing the amount of withdrawable share capital for cooperative needs or enabling the automation of cooperatives' reporting to the government, etc. [9]. These practices may be interested in cooperative management in Ukraine. On the contrary, the Kenya National Federation of Cooperatives over the years of functioning has deviated from such important missions as collaboration, lobbying, and networking to rare training sessions and consultancy. Later, the situation has worsened due to corruptive practices and eventually many member cooperatives withdraw their membership that led to its near-collapse [10, p. 9]. Factors that may lead to the deterioration in the performance of cooperatives' union has to be studied as well as good practices.

Having said that, such multi-stakeholders' structures like secondary and tertiary producers' cooperatives and their activity within rural areas of Ukraine has to be investigated.

Analysis of recent research and publications. Different types of agricultural unions and associations are there in the world for over a century. For instance, one of the firstever cooperatives' unions has been created in 1870 for all-kind support for consumers and workers' cooperatives in Rochdale, UK. Nowadays, it is still functioning by the name of 'Cooperatives UK' and concentrated on promotion, development, and uniting the cooperative enterprises [13].

Thus, the studying of cooperative has begun since the end of the $19^{\text {th }}$ century. Ingalsbe F. and Groves G. have studied the aspects of the functioning of the oldest cooperative or- 
ganisations like Rochdale Pioneers in the United Kingdom and credit cooperative started by Raiffeisen F. in Germany [12, p. 106].

Hoyt A. covered such important matters for agricultural development as attempts to organize primary and secondary cooperatives, and their potential to supply inputs and market farm products in developing countries [11, p. 82].

The recent massive of new practical information on primary and secondary dairy cooperatives came from African, Asian, and Indian farmers and scholars. There, the issues of vertical integration of agricultural cooperatives have become significant within the last tenyear period. Kwanzi M. and Mbohva C. have explored the existing cooperative model of market supply in South Africa [15]. Srinivasan S. and Sundaram B. studied the performance of agricultural cooperatives in connection with socio-economic development in Ethiopia [17, p. 200].

As of Ukrainian scholars, many have devoted their articles to different aspects of the development of the cooperative movement. Such scientist as Zinovchuk V. has dedicated all of his fundamental studies to the problem of agricultural cooperation [4]. His findings are essential for the scientific base of the Ukrainian agricultural cooperation movement.

According to the suggestions of Malik M. and Tarasov D., the cooperative movement usually develops in three basic steps. At the first step, the idea of cooperation spreads that makes many farmers try it $[6$, p. $49 ; 19]$. The next step is characterised by governments' involvement in the cooperative movement in the forms of registration and performance legislation. Moreover, the final step presents a new quality wave of cooperation based on effective interaction between all interested actors like farmers, cooperatives, consumers, factories, distributors, and government. So far, Ukrainian dairy cooperation remains at the second step meaning there is a demand for research of the described problem.

As of specifically the secondary and tertiary cooperatives in Ukraine, the studies have begun to appear since the latest nineties of 20 century. Since the beginning of the second decade of the $21^{\text {st }}$ century, many international humanitarian and technical assistance development projects have entered the Ukrainian business environment. Their outcomes usually target the capacity and competitiveness in- crease through support the grants and training for small-scale producers. Such projects provided the new database and business practices for Ukrainian scientists to research. For instance, Amelina Yu. studied the aspects of prospective cooperation of dairy and vegetable small-scale organic producers [1, p. 93]. Bezus R. and Burtak S. have studied the reasons for the crisis of Ukrainian dairy cooperatives. Also, they reveal the problem of capital structure in such cooperatives. Both of these researchers contribute to the educational support of dairy family farms, primary and secondary dairy cooperatives in Ukraine [2].

Having numerous scientists interested in studies on cooperation in Ukraine, still, there are concerns about quasi cooperatives of primal and second level contributing to the allUkrainian informational base about cooperation that may lead to negative outputs as decreasing number of real cooperatives and interested farmers in group actions.

There are few studies about the prospects for organising and developing secondary and tertiary producers' cooperatives in Ukraine.

The purpose of the article is to define the premises and prospects for organising and developing secondary and tertiary producers' cooperatives in Ukraine, specifically for dairy service cooperatives.

Research results. The current study on premises and prospects for organizing and developing dairy cooperatives in Ukraine involves the analysis of statistic data from open access sources as well as the phone and online form survey conducted by authors. Six of dairy cooperatives from Dnipro, L'viv, Zaporizhzhia, Kherson regions producing up to $20 \%$ of cooperatives' milk in Ukraine (as of 2019) have been studied. All above producers' cooperatives are members of secondary co-ops - Unions.

This study has been structured into two parts. Firstly, the authors studied the theoretical background of secondary and tertiary cooperatives including partial international practices on the studies issues. And finally, the authors determined the prospects and current issues for organising and developing secondary and tertiary farming cooperatives in Ukraine. The dairy service cooperatives were surveyed within phone and online form questioning of 10 respondents including presidents, managers, and members of the studied secondary dairy service cooperatives. 
The Ukrainian dairy farmers have several reasons to cooperate. Such as the low income of small-scale dairy farming communities. As of 2020, a large volume of raw milk in Ukraine is still produced by tiny family households. According to the State Statistic Service of Ukraine, in 2019 family households produced $71,8 \%$ of raw milk, which makes a massive reserve for milk products for both internal and external markets [8, p. 152]. However, busi- ness conditions prevent many small producers from further growing and gaining more profit.

To assess the current state of the cooperative movement in European countries with the most powerful agricultural economies. Table 1 includes indicators as the number of cooperatives, number of cooperative members, number of cooperative employees, and annual cooperatives turnover (Table 1).

Table 1. Key statistics data about cooperative movement in European countries with the most powerful agricultural economies

\begin{tabular}{|l|c|c|c|c|}
\hline \multirow{2}{*}{\multicolumn{1}{|c|}{ Indicators }} & \multicolumn{4}{c|}{ Country } \\
\cline { 2 - 5 } & France & Italy & Germany & Spain \\
\hline Number of cooperatives & 22517 & 39600 & 7500 & 20050 \\
\hline $\begin{array}{l}\text { Number of cooperative } \\
\text { members }\end{array}$ & 26106829 & 12620000 & 22200000 & 315000 \\
\hline $\begin{array}{l}\text { Number of cooperative } \\
\text { employees }\end{array}$ & 1217466 & 1150200 & 860000 & 290221 \\
\hline $\begin{array}{l}\text { Annual cooperatives turnover, } \\
\text { in billions of Euro }\end{array}$ & 307 & 150 & 195 & 22 \\
\hline
\end{tabular}

Source: Created by authors using [14, p. 12].

According to the data from the Table 1, the most developed market for cooperative agriculture has France since this country has the highest economic indicators.

The Netherlands has only 200 producers' cooperatives, which is much lower than in other European countries, but those are enough to support the efficiency of the Dutch agricultural cooperative market.

The shares of agricultural market demonstrates that cooperatives in France have 50\% of the French market, Finnish cooperatives $79 \%$, and in the Netherlands agricultural cooperatives have $83 \%$ of the agricultural market. At this point, the Ukrainian sector of cooperative agriculture has much lower performance.

With unstable prices for cattle feed and unpredictable retail prices for raw milk and handcrafted milk products, Ukrainian farmers try to cooperate to reduce the cost of milk production and its delivery to cooling points and milk plants. However, after solving the production costs issues and group sales, Ukrainian co-operators may face issues with tax and social security legislation, village in- frastructure matters influencing the speed of milk delivery, etc. Besides, small-scale producer and their unions have always to compete with agricultural enterprises and even holding companies. Protecting the rights and business interests are essential reasons for Ukrainian dairy farmers to cooperate.

About $10 \%$ of cooperatives in Ukraine are members of the secondary cooperatives (unions). The biggest union has 40 cooperatives and the total of dairy member cooperatives in this unions is 27 (table 2). 2 unions market milk to the processors however one of those has started building the processing plant. Other unions usually provide consultancy, advisory, education, and advocacy services.

The basic idea behind the cooperation of cooperatives has been described in the sixth cooperative principle. According to the International Co-operative Alliance, this principle states that "cooperatives serve their members most effectively and strengthen the cooperative movement by working together through local, national, regional and international structures" [13]. 
Table 2. Top of Ukrainian Cooperative Unions (as of 2020)

\begin{tabular}{|c|c|c|c|c|c|}
\hline № & Name & Regions & $\begin{array}{c}\text { Member } \\
\text { coops }\end{array}$ & $\begin{array}{l}\text { Dairy } \\
\text { coops }\end{array}$ & $\begin{array}{c}\text { Milk } \\
\text { sales } \\
\text { via the } \\
\text { Union }\end{array}$ \\
\hline 1 & $\begin{array}{l}\text { Cooperative union of agricultural } \\
\text { service cooperatives «Fayni Gazdy» }\end{array}$ & $\begin{array}{l}\text { Ternopil, Khmelnytsk, } \\
\text { Kyiv, Ivano-Frankivs'k, } \\
\text { Volyn }\end{array}$ & 40 & 4 & No \\
\hline 2 & $\begin{array}{l}\text { Cooperative union of agricultural } \\
\text { service cooperatives «Rivnopravnist» }\end{array}$ & $\begin{array}{l}\text { L`viv, Ternopil’, } \\
\text { Ivano-Frankivs'k }\end{array}$ & 12 & 12 & Yes* \\
\hline 3 & $\begin{array}{l}\text { Union of agricultural service } \\
\text { cooperatives «Gospodar» }\end{array}$ & $\begin{array}{l}\text { Dnipropetrovs`k, } \\
\text { Zaporizhzhia, Kherson, } \\
\text { Kirovograd }\end{array}$ & 8 & 6 & Yes \\
\hline 4 & $\begin{array}{l}\text { Union of cooperatives and private } \\
\text { entrepreneurs for production } \\
\text { of agricultural natural products } \\
\text { «Opilskyy kray» }\end{array}$ & Ivano-Frankivs'k & 4 & 1 & No \\
\hline 5 & $\begin{array}{l}\text { Union of agricultural service } \\
\text { cooperatives «Hospodar Pidhirya» }\end{array}$ & Lviv, Chernivtsi & 4 & 1 & No \\
\hline 6 & $\begin{array}{l}\text { Chernigiv regional union of agricultural } \\
\text { service cooperatives «Polissya» }\end{array}$ & Chernihiv & 3 & 2 & No \\
\hline 7 & $\begin{array}{l}\text { Union of agricultural service } \\
\text { cooperatives «Chernihivshchina } \\
\text { ekolohichna» }\end{array}$ & Chernihiv & 2 & 1 & No \\
\hline 8 & $\begin{array}{l}\text { Cooperative union of agricultural } \\
\text { service cooperatives «Agro-Yednist» }\end{array}$ & Cherkasy & 2 & 0 & No \\
\hline \multicolumn{3}{|c|}{ TOTAL } & 75 & 27 & \\
\hline
\end{tabular}

*marketing the milk via cooperative union private firm «Cooperative Solidarnist'».

Source: Created by the authors.

According to the theories and evidence from the scientific literature on the studied issue and revised dairy cooperatives, the secondary cooperatives have a structure depicted in Figure.

Historically, Ukrainian agricultural cooperators have been having constant attempts to start an efficient secondary all-Ukrainian cooperative for agricultural producers. Unfortunately, such organisations were not able to support all the cooperation actors' needs and resolve all the problems.

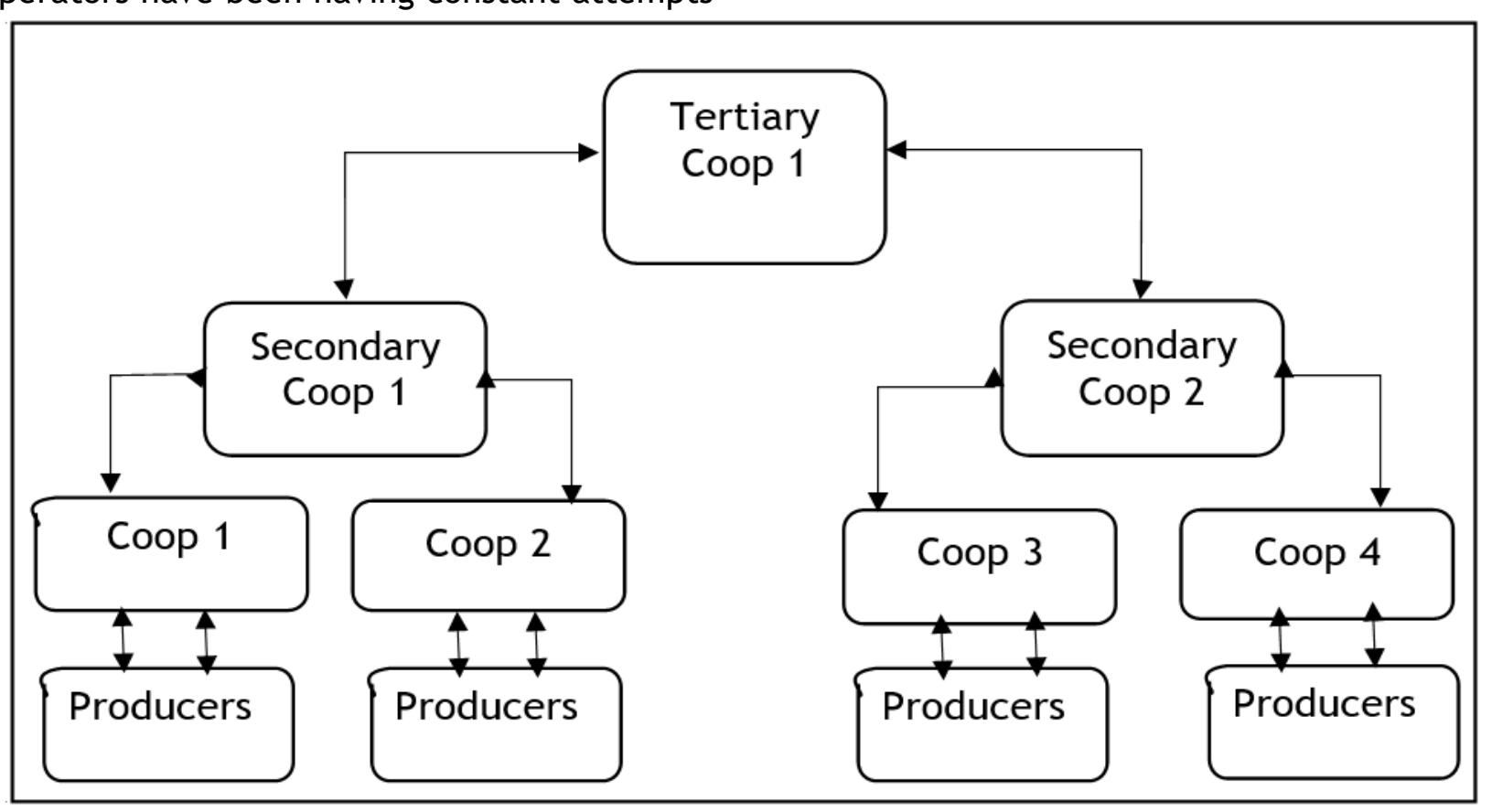

Figure. Membership in the primary, secondary, and tertiary cooperatives

Source: Created by authors. 
Since Ukraine gained independence, the cooperatives that usually were ex-collective farms united into the All-Ukrainian Comity of Cooperatives financed from farmers' social security funds. Having involuntary nature and rather political than social and economic purposes, this organisation decreased its influence within the next decade and eventually closed.

According to Zinovchuk's V. findings, after the mentioned Comity meeting in 1998, the National Association of agricultural cooperatives of Ukraine was established and became an important body for agricultural cooperatives in Ukraine. However, the evolution of this Association was not fast enough to protect agricultural cooperatives in a rapidly changing environment [19, pp. 76-77].

In 2017, 5 cooperative unions have started the first-ever tertiary cooperative in the Ukrainian agricultural sector of the economy named All-Ukrainian Agrarian Forum. In 2020, this organization is mainly busy with legislation lobbing concerning agricultural production with limited attention to dairy farmers [3].

To determine what premises and prospects the members and managers of dairy cooperatives have, the authors conducted a phone and online form survey of 10 respondents. The respondents were presidents, managers, and members of the studied secondary dairy service cooperatives.

The survey was designed in a form of wide open question: "Please name and describe premises and prospects for organising and developing secondary and tertiary dairy service cooperatives". In case, if the respondent is not able to give a detailed and structured answer, the interviewer may have asked listed specific questions:

- Why did you established or entered the secondary cooperative?

- What kind of expectations did you have before entering?

- What results did you get from the secondary cooperative?

Do you seek to enter or start the tertiary cooperative? Why?

- What purposes will it have?

All of the respondents stated that a secondary cooperative (usually union) was necessary for protecting the rights and interests of dairy cooperatives as actors of the actual Ukrainian dairy market.
$80 \%$ of respondents expected from secondary cooperative more informational support such as cooperative matters' education, sharing practices of production and administration of business, updating of technologies. $50 \%$ of respondents expected to get more information and chances for credits and funding for their cooperative from the Ukrainian government or international funding bodies. $100 \%$ of respondents expected better marketing of their milk.

$60 \%$ of respondents were satisfied with the training about cooperatives and better prices they get after joining the secondary cooperative. $70 \%$ liked the new cooling points and trucks they were able to get through funding or cheaper credit from the union. 20\% of respondents were not satisfied by their membership in a secondary dairy cooperative because of the lack of real collaboration, no transparency in its management, and low retail prices for milk.

The idea to have a big all-Ukrainian association of dairy service cooperatives (or tertiary cooperative) to solve the issues of studied cooperatives as lobbying the legislation changes, influencing the milk prices, modernising the production of milk, creating reliable credit unions are attractive for $100 \%$ of surveyed organizations. However, $90 \%$ of respondents share their doubts in a realisation of this idea. $70 \%$ of respondents expect low transparency in administrating such an organisation and subsequently high corruption level. $80 \%$ of respondents stated that tertiary cooperative would be very helpful while the land reform is happening to protect their land rights, but they do not know how to organise it. $40 \%$ of respondents think that an efficient tertiary dairy cooperative should be focused specifically on dairy service cooperative to be fully concentrated on the interests of its members and not its own services.

Thus, members and managers of surveyed secondary cooperatives are aware of prospective benefits from cooperative unions and expect something similar or even better from starting the tertiary cooperative. In Ukraine, they prefer it to be organised based on sectorial mandate and mainly concentrated on legislation and funding matters.

Conclusions. Low incomes, unsafe working conditions, long working hours, feeling of low social security, and willingness for development usually motivate Ukrainian small-scale 
dairy producers to cooperate in the hope to get better selling prices for their milk and cheaper feed and fertilisers.

The shares of agricultural markets in the European countries as France and the Netherlands are up to $83 \%$ that shows a possibility for further development for Ukrainian cooperatives, including dairy ones.

Surveyed respondents are sure that tertiary cooperative is a body for farmers' protection. The primary cooperatives start to need higher level of cooperation when they face an issues which need the legislation change or crucial for agricultural producers reforms such as land reform. Also, those organisations may be able to influence the market conditions, to

\section{Список бібліографічних посилань}

1. Амеліна Ю. С. Економічний розвиток сільськогосподаських підприємств органічного овочівництва та плодівництва : дис... канд. екон. наук: 08.0.04. Дніпропетровськ, 2016. 216 с.

2. Безус P., Буртак C. Чому кооперативи помирають в Україні? 2018. URL : https://kurkul.com/spetsproekty/248chomu-v-ukrayini-pomirayut-kooperativi.

3. Всеукраїнський аграрний форум, 2020. URL : http://unaf.org.ua/ua/.

4. Зіновчук В. В., Довженко В. А. Сільськогосподарська кооперація: проблеми та перспективи. Економіка АПК. 2017. № 9. C. 90-96. URL : http://nbuv.gov.ua/UJRN/E_apk_2017_9_17.

5. Кількість юридичних осіб за організаційно-правовими формами господарювання. Державна служба статистики України, 2020. URL : http://www.ukrstat.gov.ua/edrpoy/ukr/ EDRPU_2020/ks_opfg/ks_opfg_0720.htm.

6. Малік М. Й. Проблемні питання розвитку кооперації та інтеграційних відносин в АПК. Економіка АПК. 2010. № 3. C. 45-49.

7. Про сільськогосподарську кооперацію : Закон України № 819-ІХ від 21 липня 2020 р. / Верховна Рада України, 2020. URL : https://zakon.rada.gov.ua/laws/show/819-20\#Text.

8. Структура виробництва продукції тваринництва за видами виробників. Державна служба статистики України, 2020. URL : http://www.ukrstat.gov.ua/druk/publicat/kat_u/ 2020/zb/09/zb_sg_Ukr_2019.pdf.

9. Co-operative and Community Benefit Societies Act (2014) London. UK Law. Legislation.gov.uk. URL

https: / /www.legislation.gov.uk/ukpga/2014/14/contents.

10. Fredrick $O$. Wanyama. Surviving liberalization: the cooperative movement in Kenya. Coop Africa, Working paper. 2009. № 3. P. 9. URL : https://www.ilo.org/wcmsp5/groups/ public/---ed_emp/---emp_ent/---coop/documents/publication/ wcms_117886.pdf.

11. Hoyt $A$. Cooperatives in other countries. In Cooperatives in agriculture, ed. D. Cobia, $1989 . \quad$ P. 81-97. New Jersey, USA: Prentice-Hall, Inc.

12. Ingalsbe G., Groves F. Historical development. In Cooperatives in agriculture, ed. D. Cobia, 1989. P. 106-120. New Jersey, USA: Prentice-Hall, Inc.

13. International Co-operative Alliance. Cooperative identity, 2020. URL : https://www.ica.coop/en/cooperatives/ cooperative-identity.

14. Karakas C. Cooperatives: Characteristics, activities, status, challenges. European Parliamentary Research Service, 2019. URL : https://www.europarl.europa.eu/RegData/ etudes/BRIE/2019/635541/EPRS_BRI(2019)635541_EN.pdf.

15. Kwanzi M., Mbohva C. Exploring the Secondary Cooperative Model in the Supply of Fabric to Primary Sewing Cooperatives. Proceedings of the 2017 International Symposium on Industrial Engineering and Operations Management (IEOM), Bristol, UK, 2017. July 24-25. raise the funding or subsidies for small-scale dairy farmers.

In general, the secondary and tertiary dairy cooperatives according to the surveyed cooperators should support the farmers' negotiations in the value chain affecting the dairy farming sector: suppliers, processors, traders, government. To manage those actors in more efficient and using bargaining power on behalf of small-scale producers. Nevertheless, taking into account the existing issues of the Ukrainian business environment as corruption or shadowed economy, the governance structure, management and transparency of those secondary or tertiary levels of cooperatives are very important to gain trust of producers.

\section{References}

1. Amelina, Yu.S. (2016). Ekonomichnyi rozvytok silskohospodaskykh pidpryiemstv orhanichnoho ovochivnytstva ta plodivnytstva [Economic development of agrarian enterprises in organic olericulture and pomiculture]. Candidate's thesis. Dnipropetrovsk: DSAEU [In Ukrainian].

2. Bezus, R. \& Burtak, S. (2018). Chomu kooperatyvy pomyraiut $\vee$ Ukraini [Why coops die in Ukraine?]. Retrieved from: https://kurkul.com/spetsproekty/248-chomu-v-ukrayinipomirayut-kooperativi kurkul.com [In Ukrainian].

3. Vseukrainskyi ahrarnyi forum [All-Ukrainian Agrarian Forum]. (2020). Retrieved from: http://unaf.org.ua/ua/ [In Ukrainian].

4. Zinovchuk, V.V. \& Dovzhenko, V.A. (2017). Silskohospodarska kooperatsiia: problemy ta perspektyvy [Agricultural cooperation: problems and perspectives]. Ekonomika APK, 9, pp. 90-96. Retrieved from: http://nbuv.gov.ua/ UJRN/E_apk_2017_9_17 [In Ukrainian].

5. Kilkist yurydychnykh osib za orhanizatsiino-pravovymy formamy hospodariuvannia. Derzhavna sluzhba statystyky Ukrainy [Number of legal entities by organizational and legal forms of management]. (2020). Retrieved from: http://www.ukrstat.gov.ua/edrpoy/ukr/EDRPU_2020/ks_opfg/ ks_opfg_0720.htm [In Ukrainian].

6. Malik, M.Yo. (2010). Problemni pytannia rozvytku kooperatsii ta intehratsiinykh vidnosyn $\vee$ APK [Problematic issues of cooperation and integration relations in the agro-industrial complex]. Ekonomika APK, 3, pp. 45-49 [In Ukrainian].

7. Pro silskohospodarsku kooperatsiiu: Zakon Ukrainy \# 819-IX vid 21 lypnia 2020 r. [On Agricultural Cooperation. Law of Ukraine No. 819-IX from July 21, 2020]. (2020). Retrieved from: https: //zakon.rada.gov.ua/laws/show/819-20\#Text [In Ukrainian].

8. Struktura vyrobnytstva produktsii tvarynnytstva za vydamy vyrobnykiv [Structure of livestock production according to types of producers]. (2020). Derzhavna sluzhba statystyky Ukrainy. Retrieved from: http://www.ukrstat.gov.ua/druk/ publicat/kat_u/2020/zb/09/zb_sg_Ukr_2019.pdf [In Ukrainian].

9. Co-operative and Community Benefit Societies Act (2014). London: UK Law. Retrieved from: https://www.legislation.gov.uk/ukpga/2014/14/contents [In English].

10. Fredrick, O. Wanyama (2009). Surviving liberalization: the cooperative movement in Kenya. Coop Africa, Working paper, 3, p. 9. Retrieved from: https://www.ilo.org/wcmsp5/ groups/public/---ed_emp/---emp_ent/---

coop/documents/publication/wcms_117886.pdf [In English].

11. Hoyt, A. (1989). Cooperatives in other countries. In Cooperatives in agriculture, pp. 81-97. D. Cobia (Ed.). New Jersey, USA: Prentice-Hall, Inc [In English]. 
16. Shpykuliak O., Sakovska O. Agricultural cooperation as an innovation for rural development. Baltic Journal of Economic Studies. 2020. Vol. 6. № 3. P. 183-189. https://doi.org/ 10.30525/2256-0742/2020-6-3-183-889.

17. Srinivasan S., Sundaram B. Performance of Agricultural Cooperatives to Endorse Socio-Economic Development in Ethiopia. International Research Journal of Science and Technology. 2020. Vol. 1. Issue 3. P. 199-205.

18. Tarasov D. Key aspects of service cooperatives in the agricultural sector of Ukraine. 2014. URL: http://old.bumib.edu.ua/ sites/default/files/visnyk/stattya_tarasov_ang..doc

19. Zinovchuk V. Supporting agribusiness in Ukraine: Cooperatives and beyond, 2007. URL : http://vadyba.asu.lt/ 9/73.pdf.
12. Ingalsbe, G. \& Groves, F. (1989). Historical development. In Cooperatives in agriculture, pp. 106-120. D. Cobia (Ed.). New Jersey, USA: Prentice-Hall, Inc [In English].

13. International Co-operative Alliance (2020). Cooperative identity Retrieved from: https://www.ica.coop/en/cooperatives/ cooperative-identity [In English].

14. Karakas, C. (2019). Cooperatives: characteristics, activities, status, challenges. European Parliamentary Research Service Retrieved from: https://www.europarl.europa.eu/RegData/ etudes/BRIE/2019/635541/EPRS_BRI(2019)635541_EN.pdf [In English].

15. Kwanzi, M. \& Mbohva, C. (2017). Exploring the Secondary Co-operative Model in the Supply of Fabric to Primary Sewing Co-operatives. Proceedings of the 2017 International Symposium on Industrial Engineering and Operations Management (IEOM), Bristol, UK, July 24-25 [In English]

16. Shpykuliak, O. \& Sakovska, O. (2020). Agricultural cooperation as an innovation for rural development. Baltic Journal of Economic Studies, vol. 6(3), pp. 183-189 [In English]. https: / /doi.org/10.30525/2256-0742/2020-6-3-183-889.

17. Srinivasan, S. \& Sundaram, B. (2020). Performance of Agricultural Cooperatives to Endorse Socio-Economic Development in Ethiopia International Research Journal of Science and Technology, vol. 1 (3), pp. 199-205 [In English].

18. Tarasov, D. (2014). Key aspects of service cooperatives in the agricultural sector of Ukraine. Retrieved from: http://old.bumib.edu.ua/sites/default/files/visnyk/stattya_tar asov_ang.doc [In English].

19. Zinovchuk, V. (2007), Supporting agribusiness in Ukraine: Cooperatives and beyond. Retrieved from: http://vadyba.asu.lt/9/73.pdf [In English].

Безус Р. М., Буртак С. Г., Крючко Л. С., Дуброва Н. П. Передумови і перспективи організації та розвитку сільськогосподарських кооперативів другого і третього рівнів в Україні: приклад молочних обслуговуючих кооперативів

Мета статті - виявити передумови і перспективи організації та розвитку сільськогосподарських кооперативів другого і третього рівнів в Україні, зокрема молочних обслуговуючих кооперативів.

Методика дослідження. Використано методи: діалектичного пізнання та монографічний - для аналізу робіт українських і зарубіжних вчених із проблеми сільськогосподарської молочної кооперації; емпіричні й графічні - для демонстрації стану кооперативного руху в європейських країнах і взаємодії кооперативів трьох рівнів; дистанційного опитування - для з'ясування думки кооператорів про сільськогосподарські кооперативи другого і третього рівнів; абстрактно-логічні - для теоретичних узагальнень і формулювання висновків.

Результати дослідження. Встановлено, що більшість кооператорів прагнуть до колективного вирішення проблем конкурентного ділового середовища в Україні. Функціонування об'єднань молочних кооперативів (кооперативів другого рівня) дозволило поліпшити взаємодію між учасниками молочного бізнесу $і$ сприяло кращій організації сільськогосподарського виробництва в сільських громадах. На думку респондентів, кооператив третього рівня покликаний підтримувати фермерів і кооперативи при вирішенні таких істотних проблем, як обмежувальне законодавство, або в процесі таких критично важливих реформ для сільськогосподарських виробників, як земельна. Ці організації можуть мати можливість впливати на ринкові умови, залучати фінансування або субсидії для дрібних молочних виробників.

Елементи наукової новизни. Визначено причини кооперації дрібних молочних фермерів і їхні думка про передумови та перспективи організації та розвитку сільськогосподарських кооперативів другого і третього рівнів в Україні. Позначено перспективні точки розвитку і вдосконалення цих організацій з метою підтримки функціонування сільського молочного бізнесу в Україні. Зокрема, респонденти кооперативів другого рівня обізнані про передбачувані вигоди від кооперативних об'єднань і чекають подібного від створення кооперативу третього рівня. Вони очікують, що він буде організований на основі галузевих повноважень і в основному зосереджений на питаннях законодавства та фінансування. Разом із тим 80\% респондентів сумніваються в практичній реалізації цієї ідеї через ризики корупції та тінізації економіки. При цьому об'єднання кооперативів є діловими організаціями, а в контексті світового досвіду спрямовані на маркетинг, переробку або торгівлю продукцією, здобуття переговорної сили та частки ринку.

Практична значущість. Вчені та експерти аграрної економіки можуть використовувати результати дослідження для підтримки розвитку молочних обслуговуючих кооперативів другого і третього рівнів в Україні, для поліпшення умов праці в селах із кооперативами та бізнес-середовища для дрібних виробників молочної продукції в Україні. Табл.: 2. Рис.: 1. Бібліогр.: 19.

Ключові слова: сільськогосподарські кооперативи; молочні кооперативи; кооперативи; об'єднання кооперативів; вторинні і третинні кооперативи.

Безус Роман Миколайович - доктор економічних наук, професор, професор кафедри маркетингу, Дніпровський державний аграрно-економічний університет (49600, м. Дніпро, вул. С. Єфремова, 25)

E-mail: bezusrm@gmail.com

ORCID iD http://orcid.org/0000-0001-5284-9178

Буртак Софія Григорівна - кандидат політичних наук, менеджер тренінгових і гендерних програм, Кооперативна Академія (49000, м. Дніпро, просп. П. Калнишевського, 31)

E-mail: sofia.burtak@gmail.com

ORCID iD http: //orcid.org/0000-0002-8578-0741

Крючко Леся Станіславівна - кандидат економічних наук, доцент кафедри маркетингу, Дніпровський державний аграрно-економічний університет (49600, м. Дніпро, вул. С. Єфремова, 25)

E-mail: kriuchko.l.s@dsau.dp.ua

ORCID iD http://orcid.org/0000-0002-7490-3523 
Дуброва Наталія Петрівна - кандидат економічних наук, доцент кафедри фінансів, банківської справи та страхування, Дніпровський державний аграрно-економічний університет (49600, м. Дніпро, вул. С. Єфремова, 25) E-mail: pts_fkg@meta.ua ORCID iD http://orcid.org/0000-0001-8584-3338

Безус Р. Н., Буртак С. Г., Крючко Л. С., Дуброва Н. П. Предпосылки и перспективы организации и развития сельскохозяйственных кооперативов второго и третьего уровней в Украине: пример молочных обслуживающих кооперативов

Цель статьи - выявить предпосылки и перспективы организации и развития сельскохозяйственных кооперативов второго и третьего уровней в Украине, в частности молочных обслуживающих кооперативов.

Методика исследования. Использованы методы: диалектические познания и монографический - для анализа работ украинских и зарубежных ученых по проблеме сельскохозяйственной молочной кооперации; эмпирические и графические - для демонстрации состояния кооперативного движения в европейских странах и взаимодействия кооперативов трёх уровней; дистанционного опроса - для выяснения мнения кооператоров о сельскохозяйственных кооперативах второго и третьего уровней; абстрактно-логические - для теоретических обобщений и формулировки выводов.

Результаты исследования. Установлено, что большинство кооператоров стремятся к коллективному решению проблем конкурентной деловой среды в Украине. Функционирование объединений молочных кооперативов (кооперативов второго уровня) позволило улучшить взаимодействие между участниками молочного бизнеса и способствовало лучшей организации сельскохозяйственного производства в сельских общинах. По мнению респондентов, кооператив третьего уровня призван поддерживать фермеров и кооперативы при решении таких существенных проблем, как ограничительное законодательство, или в процессе таких критически важных реформах для сельскохозяйственных производителей, как земельная. Эти организации могут иметь возможность влиять на рыночные условия, привлекать финансирование или субсидии для мелких молочных фермеров.

Элементы научной новизны. Определены причины кооперации мелких молочных фермеров и их мнение о предпосылках и перспективах организации и развития сельскохозяйственных кооперативов второго и третьего уровней в Украине. Обозначены перспективные точки развития и совершенствования этих организаций с целью поддержки функционирования сельского молочного бизнеса в Украине. В частности, респонденты кооперативов второго уровня осведомлены о предполагаемых выгодах от кооперативных объединений и ожидают подобного от создания кооператива третьего уровня. Они ожидают, что он будет организован на основе отраслевых полномочий и в основном сосредоточен на вопросах законодательства и финансирования. Вместе с тем $80 \%$ респондентов сомневаются в практической реализации этой идеи из-за рисков коррупции и тенизации экономики. При этом, объединения кооперативов являются деловыми организациями, а в контексте мирового опыта направлены на маркетинг, переработку или торговлю продукцией, получение переговорной силы и доли рынка.

Практическая значимость. Учёные и эксперты аграрной экономики могут использовать результаты исследования для поддержки развития молочных обслуживающих кооперативов второго и третьего уровней в Украине, для улучшения условий труда в селах с кооперативами и бизнес-среды для мелких производителей молочной продукции в Украине. Табл.: 2. Илл.: 1. Библиогр.: 19.

Ключевые слова: сельскохозяйственные кооперативы; молочные кооперативы; кооперативы; объединения кооперативов; вторичные и третичные кооперативы.

Безус Роман Николаевич - доктор экономических наук, профессор, профессор кафедры маркетинга, Днепровский государственный аграрно-экономический университет (49600, г. Днепр, ул. С. Ефремова, 25)

E-mail: bezusrm@gmail.com

ORCID iD http://orcid.org/0000-0001-5284-9178

Буртак София Григорьевна - кандидат политических наук, менеджер тренинговых и гендерных программ, Кооперативная Академия, (49000, г. Днепр, просп. П. Калнышевского)

E-mail: sofia.burtak@gmail.com

ORCID iD http://orcid.org/0000-0002-8578-0741

Крючко Леся Станиславовна - кандидат экономических наук, доцент кафедры маркетинга, Днепровский государственный аграрно-экономический университет (49600, г. Днепр, ул. С. Ефремова, 25)

E-mail: kriuchko.l.s@dsau.dp.ua

ORCID iD http: //orcid.org/0000-0002-7490-3523

Дуброва Наталья Петровна - кандидат экономических наук, доцент кафедры финансов, банковского дела и страхования, Днепровский государственный аграрно-экономический университет (49600, г. Днепр, ул. С. Ефремова, 25)

E-mail: pts_fkg@meta.ua

ORCID iD http://orcid.org/0000-0001-8584-3338

The article has been received 12.11.2020

Revision: 20.11.2020

Бібліографічний опис для цитування:

Bezus R. M., Burtak S. H., Kriuchko L. S., Dubrova N. P. Premises and prospects for organising and developing secondary and tertiary producers' cooperatives in Ukraine: the case of dairy service cooperatives. Економіка АПК. 2020. № 11. С. 90 - 98. https://doi.org/10.32317/2221-1055.202011090

Bezus, R.M., Burtak, S.H., Kriuchko, L.S. \& Dubrova, N.P. (2020). Premises and prospects for organising and developing secondary and tertiary producers' cooperatives in Ukraine: the case of dairy service cooperatives. Ekonomika APK, 11, pp. 90 - 98 [In English] https://doi.org/10.32317/2221-1055.202011090 